J. Product. \& Dev., 25(2): 149-168(2020)

\title{
SUPPLEMENTATION OF BIO-YOGHURT WITH JERUSALEM ARTICHOKE (Helianthus tuberous $L$.) as a NATURAL SOURCES.
}

\author{
A.S. h. T. Bakr*; Moussa, M. A. M.**and EL-Shahawy, A. M** \\ *Fac.Agric, Tanta Univ, Tanta, Egypt \\ **Animal Pro. Res. Instute, Agric. Res. Center, Ministry of Agric, Egypt. \\ **Amina Mahammad Amyntalshhawy@gmail.com
}

\section{ABSTRACT}

Used Helianthus tuberous(Jerusalem artichoke)as supplement to product function yoghurt to enhance native value health benefits and to improve rheological,phyisco-chemical and sensory properties of final product. Yoghurt was made from fresh cow's milk fortificaed with the conventionl yoghurt starter culture containing Bifidobacterim bifidum, Streptococcus thermophilus and Lactobacillus acidophilus .Jerusalem artichoke extract( JAE) was added at levels 3,5and 7\%.then storage for 15 days, at $5 \pm 1{ }^{\circ} \mathrm{C}$.

Results showed that moisture content was increase by increasing addition rate of JAE unit $7 \%\left(T_{3}\right)$ No significant difference between the control sample and the treated sample of protein, fat and ash. There were significant increase of fibers content in all treatment, compared with control. Yoghurt with $7 \%\left(T_{3}\right)$ had the highest content of amino acids compare with other treatments and control the data also showed that $\left(T_{2}\right)$ supplementation yoghurt with (JAE) (5\%)had the highest content of vitB 3 $T_{3}$ compared with other treatments. No-significant decrease in PH values at $3 \%$ JAE compared to the control sample at zero time Meanwhile, this decrease became significant with treatments 3, 5and 7\%JAE at zero 5,10 and 15 days storage.

The rate of syneresis increase by the rate of JAE till7\% comparing with control. Yoghurt supplementated by 5\% JAE demonstrated a high rheological and phisco-chemical properties than ather treatment and control The total viable bacterial count TVBC between the control and the treated sample with 3\% JA E had no significance difference compared to sample contained 7\% JAE. lactic acid bacteria showed higher and progressive increase as seen in the amples contained JA E at levels of 3, 5 
and $7 \%$ resulted in highly significance between treated samples and the control Molds and yeasts enumeration of Bio-yoghurt as affected by supplementing with JAE are registered in the same table. No numbers of these populations recorded in fresh samples as affected by higher heat of milk and the used ingredients and phenolic compounds contained in both Jerusalem artichoke. Psychrophilic bacteria showed that it did not detect in Bio- yoghurt wither supplemented with JAE at different levels of supplementation.

Conclusively, from these results, it could be concluded that supplementation dairy products with Jerusalem artichoke as treatment for diabetes. Because if it was approved that it reduces the level of glucose in blood, because they contain many vitamins and nutrients necessary and beneficial to human health.

Key words: Supplementation, bio-yoghurt, jerusalem artichoke, (helianthus tuberous $l$., natural sources

\section{INTRODUCTION}

In Egypt yoghurt is one of the most popular fermented milk products and throughout the world for its therapeutic benefits and nutritional impact. The individuality of yoghurt is credited to the interdependent fermentation involved in its making. However, flavor and texture of the products are the most distinct factors that affect the superiority and acceptance of consumer to yoghurt. So, it is well known that the marketability of any food product is dependent upon four factors, namely, body, texture, flavor and shelf-life. Body and texture point to the physical nature of product. Compactness, consistency, resilience, viscosity... etc are terms that denote "body" characteristics. Texture describes the fine structure of a substance or its feel. Grainy, sandy, smooth and slimy are a few of the terms used in describing textural characteristics. As early as 1975, Nielson demonstrated that the factors that affect body, texture and flavor of yoghurt are: composition of the yoghurt mix, homogenization of the mix, heat treatment of the mix prior to inoculation, starter culture and incubation condition, handling of the ripened yoghurt and stabilizers used.

The efficiency of added probiotic bacteria depends on dose level, their viability must be maintained throughout storage, and they must survive in the gut environment (Kailasapathy and Chin, 2000; Aryana and McGrew, 2007). 
In order to improve these features of probiotic bacteria, fermented food should be supplemented with prebiotics. There are non-digestible food ingredients that beneficially affect the host by selectively stimulating the growth and/or activity bacteria in the colon (probiotics). Fructooligosaccharides (FOS) and inulin are among the most famous prebiotic compounds (Buriti et al., 2007; Cardarelli et al., 2007).

There is species improtent in the food industry will be mentioned. $S$. thermophilus is used in the manufacture of yoghurt. Lactococci, primarily $L$. lactis, are associated with the dairy industry and the latter is actually used in dairy technology. Species of Lactobacillus, such as L. acidophilus, $L$. delbruckii. L. planetarium, and L. bulgaricus, etc. are known in food technology. Homo fermentative lactic acid bacteria use the glycolysis, also known as the Embden-Meyerhof pathway, for hexose fermentation (Axelsson and Bjomsson, 1992).

Jerusalem artichoke (Helianthus tuberous L.) is a native plant of the North American plains cultivated for different purposes in many countries. Jerusalem artichoke is a natural raw material for the derivation of a number of functional food ingredients such as inulin, oligo fructose and fructose (Kays and Nottingham, 2007) having both nutritional and functional attributes, particularly beneficial to individuals with Type 2 diabetes and obesity (Niness, 1999).

The tuber contains high amount of dietary fiber namely inulin and fructo-oligosaccharides. Inulin is a polysaccharide. Chemically, it is a linear biopolymer o $\mathrm{D}$-fructose units connected by $\beta(2,1)$ glycoside linkages, and terminated with one D-glucose molecule linked to the fructose chain by an $\alpha$ $(2,1)$ bond. The degree of polymerization of inulin generally ranges from 2 to 60unit. Inulin has been increasingly used as functional ingredients in processed foods due to its unique characteristics (Nair et al., 2010).

In addition, inulin and (FOS) improve bioavailability of minerals such as calcium, magnesium and iron, increase activity of beneficial live active cultures and inhibition of harmful bacteria in the digestive tract. Inulin facilitates the digestion of high protein diets, retards fat absorption, and provides roughage preventing constipation, remains in digestive tract providing satiety without carrying of extra calories, lowers blood cholesterol and triglycerides (Letexier et al. 2003), helps with blood glucose control for 
diabetics (Tanjor et al., 2012)and decreases incidence of colon cancer (Aryana and McGrew, 2007).

Jerusalem artichoke had long been recognized for their health benefits and nutritional value, as they are rich in fiber, protein and natural sugars

Therefore, this study was curried out to use the tuber in supplementing dairy probiotic product(yoghurt) and study their effect on chemical, physicochemical, rheological, sensory characteristics and microbial aspects. Also the tubers is analyzed for their content of fibers, protein, ash, fat, water soluble vitamins and amino acid.

\section{MATERIALS AND METHODS}

Raw Materials: Jerusalem artichoke tubers (Helianthus tuberous L.) were obtained from Horticultural Research Station, Agric. Res. Center, Dokki, Gezia, Egypt during season(2019).

Milk: Raw cow's milk was obtained from the herd of Sakha Animal Research Station, Animal Production Research ,Ministry of Agriculture Egypt.

Starter culture (ABT): Starter culture (ABT) containing a mix of Streptococcus saliva rius ssp. Thermophilus (ST), Lactobacillus acidophilus (LB) and Bifidobacteriumsp. Biffidum (BB) strains which used for yoghurt production were purshed from Micro Unit (CAIRO MIRCEN), Fac. of Agric., Am Shams Univ., Cairo. Egypt.

Methods: Preparation of Jerusalem artichoke extract. Tubers were washed with tap water and any deteriorated parts were removed, than the tubers were sliced and divided to reasonable thickness by conventional food slicing machine. The sliced tubers were immersed immediately in boiling water for 2 $\mathrm{mm}$ following by immediate dipping in cold citric acid solution $(0.5 \%)$ to inhibit polyphenol oxidase activity, then Jerusalem artichoke tuber were dried

Five gram of Jerusalem artichoke powder were suspended with distilled water to give a final volume $100 \mathrm{ml}$, then agitated at $76^{\circ} \mathrm{C} \pm \mathrm{I} .0^{\circ} \mathrm{C}$ for $20 \mathrm{~mm}$ using shaker. The residue was separated by refutation according to (E1-Kboly and Mahrous, 2015) with some modification that slices of tuber were dried in air oven at $55-65^{\circ} \mathrm{C}$ until samples reached constant weight. The recovered 
powder was preserve in tight polyethylene bags and stored under freezing until use according to El-Kholy and Mahrous, (2015).

\section{Manufacturing of fortified Bio - yoghurt:}

Jerusalem artichoke tuber extract was added to cow's milk at ratio $0,3,5$ and $7 \%(\mathrm{v} / \mathrm{v})$ before the inoculation step to be as a source of inulin (prebiotic) besides adding the equal amount of skimmed powder milk to replace the dilution resulted from the addition of the prebiotic. Fortified cow's milk was heated to $90^{\circ} \mathrm{C}$ for $5 \mathrm{~min}$, then cooled to $45^{\circ} \mathrm{C}$ where inoculated with $4 \% \mathrm{~S}$. thermophiles, L.acidophillus and Bifidobacteria spp. The inoculated mixtures were mixed thoroughly, dispensed in $100 \mathrm{ml}$ polystyrene cups and incubated at $42^{\circ} \mathrm{C}$ until a uniform coagulation was formed as reported (Barrantes et al., 1994). Cups were kept at $5 \pm 1^{\circ} \mathrm{C}$ in refrigerator and analyzed after $0,5,10$ and 15 days.

\section{Chemical Analysis:}

Moisture content: Crude fat, crude protein, Fiber, Ash and total solids were estimated according to the methods described in A.0.A.C.(2005).

\section{Total carbohydrates}

The standard method of the (A.O.A.C., 2000) was used. This was determined by the differences between the whole sample and the sum of the liquid, ash, protein, and the fiber composition of the sample.

$\%$ Carbohydrate $=100-[\%$ Protein $+\%$ Fat $+\%$ Ash $+\%$ Crude Fiber $]$.

\section{Determination of lactose content:}

The lactose content was determined by subtracting the fat, protein and total ash percentages from the percentage of the total solid as described by $\mathrm{O}$, Mahoney (1988).

Amino acid composition: Amino acid composition was determined by acid hydrolysis according to Block et al. (1958).

\section{Rheological properties}

Determination of Synersis (\%) in yoghurt: About, $100 \mathrm{ml}$ of yogurt samples was placed in a graduated cylinder and stored at $4^{\circ} \mathrm{C}$ for hours: The volume of whey was measured. The synersis index (\%) was measured as milliliters of whey per $100 \mathrm{gm}$ of initial sample by using the method given by Staffolo et al. (2004). 
Curd tension in yoghurt: Curd tension was estimated in yoghurt according to Abd El-Salam et al. (1991).

Determination of Viscosity: Yoghurt samples were gently stirred 5 times in clockwise direction with plastic spoon prior to viscosity measurements. Apparent viscosity was measured at $7^{\circ} \mathrm{C}$ using a Brookfield digital viscometer (Model DV-E, Spindle-63. rpm, 50 in yoghurt, while ice cream was spindle-64.rpm,80, Canada). The sample was subjected to shear rates. Viscosity was expressed as (CP) according to El Shenawy et al.(2012).

\section{Microbiological analysis}

Total lactic acid bacteria: Lactic acid bacteria count was determined according to the methods described by the American Public Health Association (1992).

Total bacterial count: Total bacterial count of samples was determined by transferring a proportion dilution into a sterile plates and pouring with plat count agar medium. The plates were incubated at $37^{\circ} \mathrm{C}$ for $48 \mathrm{hrs}$. The colonies were counted and results were expressed as total bacterial count per gram of samples according to Difco (1984).

Mold and yeast: One $\mathrm{ml}$ from the first dilution in triplicate was transferred into sterile petri plates. The plates poured with potato dextrose agar medium and incubated at $24^{\circ} \mathrm{C}$. The plates were successively for yeast and mold after 3 days of incubated up to 5 days according to Difco (1984).

Psychrophilic bacteria: Psychrophilic bacteria were detected by following the method of Difco (1984) using nutrient agar medium. The plates were incubated at $7^{\circ} \mathrm{C}$ for 5 days.

\section{Sensory evaluation}

\section{Sensory evaluation of Bio-yoghurt:}

Sensory evaluation of yogurt samples was performed at day $\mathrm{O}$ and after 15 days of storage at $5 \pm 1{ }^{\circ} \mathrm{C}$. group of panelists consisting of 10 members from department of Animal Production Research Station, Sakha, Kafr ELSheikh and some consumers the yoghurt samples presented in coded cups inside the individual booths at room temperature. Sensory score with degrees of intensity of yoghurt attributes such as appearance, color, texture, flavor, 
and overall acceptance was used. Scoring was performed according to Kailasapathy (2006).

\section{Statistical analysis}

Data were assessed using SPSS (1997) for Microsoft Windows. Statistical results were analyzed by Duncan (1955) Multiple-Range-Test at the $\mathrm{P}<0.05$ level of significance.

\section{RESULTS AND DISCUSSION}

Table (1) demonstrates the proximate chemical composition of B-yoghurt supplemented with different levels of Jerusalem artichoke extract at zero time. Obtained data showed little increase in moisture content with increasing the added ratio of Jerusalem artichoke extract up to the ratio 3,5,7\% giving the values $(84.95,85.55,86.67$ and $86.77 \%$ ) for $\mathrm{C}, \mathrm{J} 1, \mathrm{~J} 2$ and $\mathrm{J} 3$; respectively.

There was a decrease was shown in protein, ash, and fat contents by increasing the ratios $(3,5$ and $7 \%$ extract). The values ranged from 3.38 to $3.67 \%, 1.25$ to $1.08 \%$ and from 1.27 to $0.99 \%$ for protein, ash and fat content respectively compared to the control. On the other hand, fibers showed progressive increase with significance between differences of the samples as Jerusalem artichoke extract ratios increase recording average values ranged from 0.03 to $0.09 \%$. Total solids decreased progressively by increasing the added ratios of JA extract with average values ranging from 13.09 to $13.30 \%$.

Table (1). Proximate chemical composition of Fresh JA Bio-yoghurt supplemented with different levels of Jerusalem artichoke extract.

\begin{tabular}{|c|c|c|c|c|c|c|c|}
\hline Samples & Moisture & Protein & Ash & Fat & Fiber & $\begin{array}{c}\text { Total } \\
\text { Carbohydrate }\end{array}$ & T.S \\
\hline $\mathrm{C}$ & $84.95^{\mathrm{ab}}$ & $3.38^{\mathrm{ab}}$ & $1.25^{\mathrm{a}}$ & $1.27^{\mathrm{a}}$ & $0.00^{\mathrm{b}}$ & $8.100^{\mathrm{a}}$ & $13.09^{\mathrm{ab}}$ \\
\hline $\mathrm{J}_{1}$ & $85.55^{\mathrm{ab}}$ & $3.67^{\mathrm{a}}$ & $1.19^{\mathrm{a}}$ & $1.23^{\mathrm{a}}$ & $0.03^{\mathrm{a}}$ & $7.797^{\mathrm{b}}$ & $13.55^{\mathrm{a}}$ \\
\hline $\mathrm{J}_{2}$ & $86.67^{\mathrm{a}}$ & $3.30^{\mathrm{b}}$ & $1.10^{\mathrm{ab}}$ & $1.08^{\mathrm{ab}}$ & $0.04^{\mathrm{a}}$ & $8.185^{\mathrm{ab}}$ & $13.34^{\mathrm{a}}$ \\
\hline $\mathrm{J}_{3}$ & $86.77^{\mathrm{a}}$ & $3.40^{\mathrm{a}}$ & $1.08^{\mathrm{b}}$ & $0.99^{\mathrm{b}}$ & $0.09^{\mathrm{a}}$ & $8.577^{\mathrm{a}}$ & $13.30^{\mathrm{a}}$ \\
\hline
\end{tabular}

a.b ..Means in the same column are bearing different superscripts differ significantly $(\mathrm{P}<0.05)$. JAE $=$ Jerusalem artichoke Extract, $\mathrm{C}=\mathrm{Control}=100 \%$ cow milk, J1=3\% JAE J2 $=5$ $\% \mathrm{JAE} \mathrm{J} 3=7 \%$.

Amino acid composition content of fresh Bio- yoghurt supplemented at different levels with Jerusalem artichoke extract at zero time are presented by 
Table (2). Obtained data cleared that there was progressive increase in total amino acids with significance among samples as the added ratio of JAE increased up to the ratio $7 \%$ achieving the values $(0.83,1.24,1.74 \mathrm{gl} 100 \mathrm{~g})$ for the samples $\mathbf{J}_{1}, \mathbf{J}_{2}$ and $\mathbf{J}_{3}$, respectively as compared to the control $(1.22 \mathrm{~g} \backslash 100 \mathrm{~g})$.

For the control, $\mathrm{J}_{1}, \mathrm{~J}_{2}$, and $\mathrm{J}_{3}$ samples, respectively with significant increase in differences among the control and the treatments $\mathrm{J}_{1}$ and $\mathrm{J}_{2}$, but this significance was decreasing with the treatment $\mathbf{J}_{3}$.that show progressive increase up to the ratio $7 \%\left(\mathrm{~J}_{3}\right)$ and significance between difference respectively. This increase in amino acids content often because of its higher content in Jerusalem artichoke tubers. The same table also shows that, threonine, leucine, tyrosine and arginine showed considerable decrease with the ratio 3 and $5 \%$ then increased by increasing the added ratio of JA extract giving the values ranged from, 0.03 to $0.33 \mathrm{gl} 100 \mathrm{~g}$ as compared to the control $(0.13 \mathrm{gl} 100 \mathrm{gm})$ for threonine. The same trend was observed for isoleucine and leucine that ranged from 0.13 to 0.17 and 0.13 to $0.27 \mathrm{~g} \backslash 100 \mathrm{~g}$; respectively When compared to the control $(0.22 \mathrm{~g} \backslash 100 \mathrm{~g})$ respectively. Regularly, the NEAA; Glutamic acid and alanine behaved the same behavior and the higher content observed of the first component was with $\mathrm{J} 2(0.93 \mathrm{gl} 00 \mathrm{gm})$ followed by the control sample $(0.31 \mathrm{~g} \backslash 100 \mathrm{~g})$.

In general, considerable increase was shown in both TEAA, TNEAA and TAA, the treatment $\mathrm{J} 2$ showed the highest value (3.62) of TAA followed by $\mathrm{J} 3$ (3.45), $\mathrm{J} 1$ (2.90) and the control (2.36g】 00g), respectively.

Vitamin B complex (water-soluble vitamins) of Fresh Bio-yoghurt supplemented with different levels of Jerusalem artichoke Extract (ug/g) are shown in Table (3). Exhibited data showed that the control sample contained the highest content of Vit $B_{3}(4.03 \mathrm{ug} / \mathrm{g})$ followed by the sample $\mathrm{J}_{2}$ with $5 \%$ (3.69 and the sample with $7 \%$ extract $\mathrm{J}_{3}\left(2.02 \mathrm{ug} \mathrm{gg}\right.$ ) and $\mathrm{J}_{1}$ (1.36ug $\backslash \mathrm{g}$ ) respectively.

In general, it could be observed that Vit. $B_{3}, B 1$ and Vit. $B_{2}$ decreased because of the consumption of these vitamins by the other organisms may be, $(L$. acidophilus On the other hand, B. bifidum produce B vitamins especially, pyridoxine during the manufacture of yoghurt (El-Sayed et al., 2013). This was in agreement with those of Champagne et al.,(2010) who reported an increase in pyridoxine concentration because of fermentation with $S$. thermophiles and Bifidobacteria spp. It also could observed that both Vit.B9 and Vit.B12 did not detected in the product weather the control or the treatments. Moreover, Vit. C. increased steadily by increasing the added of Jerusalem extract showing the values ranging from 2.53 to $3.67 \mathrm{ug} / \mathrm{g}$ compared to the control. 
Table (2): Amino acid composition of Fresh Bio- yoghurt supplemented with different levels of Jerusalem artichoke extract (g\l00g).

\begin{tabular}{|l|l|l|l|l|l|}
\hline \multicolumn{2}{|c|}{ Amino acid } & \multicolumn{2}{c|}{$\begin{array}{c}\text { Control } \\
\text { Sample }\end{array}$} & \multicolumn{3}{c|}{ Treatments } \\
\cline { 3 - 5 } Essential amino acids $(\boldsymbol{E A A})$ & $\mathbf{J}_{1}$ & $\mathbf{J}_{2}$ & $\mathbf{J}_{3}$ \\
\hline Threonine & $0.13^{\mathrm{b}}$ & $0.03^{\mathrm{d}}$ & $0.15^{\mathrm{c}}$ & $0.33^{\mathrm{a}}$ \\
\hline Valine & $0.08^{\mathrm{c}}$ & $0.22^{\mathrm{a}}$ & $0.04^{\mathrm{d}}$ & $0.11^{\mathrm{b}}$ \\
\hline Methionine & $0.07^{\mathrm{c}}$ & $0.11^{\mathrm{b}}$ & $0.05^{\mathrm{d}}$ & $0.19^{\mathrm{a}}$ \\
\hline Isoleucine & $0.13^{\mathrm{b}}$ & $0.11^{\mathrm{c}}$ & $0.04^{\mathrm{d}}$ & $0.17^{\mathrm{a}}$ \\
\hline Leucine & $0.22^{\mathrm{b}}$ & $0.13^{\mathrm{c}}$ & $0.06^{\mathrm{d}}$ & $0.27^{\mathrm{a}}$ \\
\hline Phenyl alanine & $0.17^{\mathrm{a}}$ & $0.02^{\mathrm{c}}$ & $0.13^{\mathrm{b}}$ & $0.16^{\mathrm{a}}$ \\
\hline Tyrosine & $0.15^{\mathrm{b}}$ & $0.03^{\mathrm{c}}$ & $0.13^{\mathrm{b}}$ & $0.31^{\mathrm{a}}$ \\
\hline Lysine & $0.14^{\mathrm{b}}$ & $0.08^{\mathrm{c}}$ & $0.23^{\mathrm{a}}$ & $0.04^{\mathrm{d}}$ \\
\hline Histidine & $0.05^{\mathrm{c}}$ & $0.06^{\mathrm{c}}$ & $0.35^{\mathrm{a}}$ & $0.11^{\mathrm{b}}$ \\
\hline Arginine & $0.08^{\mathrm{b}}$ & $0.07^{\mathrm{b}}$ & $0.19^{\mathrm{a}}$ & $0.16^{\mathrm{a}}$ \\
\hline Total EAA & $1.22^{\mathrm{c}}$ & $0.83^{\mathrm{d}}$ & $1.24^{\mathrm{b}}$ & $1.74^{\mathrm{a}}$ \\
\hline Non -Essential amino acids & \multicolumn{5}{|c|}{} \\
\hline Asportic acid & $0.32^{\mathrm{ab}}$ & $0.11^{\mathrm{c}}$ & $0.35^{\mathrm{a}}$ & $0.11^{\mathrm{c}}$ \\
\hline Glutamic acid & $0.53^{\mathrm{b}}$ & $0.22^{\mathrm{d}}$ & $0.93^{\mathrm{a}}$ & $0.31^{\mathrm{c}}$ \\
\hline Serine & $0.05^{\mathrm{c}}$ & $0.06^{\mathrm{c}}$ & $0.19^{\mathrm{a}}$ & $0.15^{\mathrm{b}}$ \\
\hline Proline & $0.04^{\mathrm{b}}$ & $0.05^{\mathrm{b}}$ & $0.02^{\mathrm{c}}$ & $0.08^{\mathrm{a}}$ \\
\hline Alanine & $0.07^{\mathrm{c}}$ & $0.11^{\mathrm{b}}$ & $0.08^{\mathrm{c}}$ & $0.18^{\mathrm{a}}$ \\
\hline Glycine & $0.05^{\mathrm{b}}$ & $0.02^{\mathrm{c}}$ & $0.18^{\mathrm{a}}$ & $0.06^{\mathrm{b}}$ \\
\hline Cystine & $0.03^{\mathrm{b}}$ & $0.04^{\mathrm{a}}$ & $0.01^{\mathrm{c}}$ & $0.05^{\mathrm{a}}$ \\
\hline Tyrosine & $1.08^{\mathrm{b}}$ & $1.46^{\mathrm{a}}$ & $0.47^{\mathrm{d}}$ & $0.77^{\mathrm{c}}$ \\
\hline Total NEAA & $2.17^{\mathrm{ab}}$ & $2.07^{\mathrm{b}}$ & $2.22^{\mathrm{a}}$ & $1.71^{\mathrm{c}}$ \\
\hline
\end{tabular}

a.b ..Means in the same column are bearing different superscripts differ significantly $(\mathrm{P}<0.05)$.

$\mathrm{C}, \mathrm{J} 1, \mathrm{~J} 2 \mathrm{and} 3 \mathrm{as}$ indicted (3,5and 7\%).

Table (4) illustrates the change in $\mathrm{pH}$ values of Bio-Yoghurt supplemented with different levels of Jerusalem artichoke extract at zero time and stored for 15 days at $5 \pm 1 \mathrm{C}$. Obtained data showed that no-significant decrease in $\mathrm{pH}$ values at the level of the treatment supplemented with $3 \%$ JAE as compared to the control sample at zero time. Meanwhile, this decrease became significant with treatments 3,5 and $7 \%$ JA extract at zero, after 5,10 and 15 days with the exception of the treatment $\mathrm{J} 3$ at the level of the day $10^{\text {th }}$ of storage which showed non-significant increase with this parameter for the ratio 5\% JAE when compared to the control.

This decrease in $\mathrm{pH}$ values with increasing the added JAE could be attributed to increasing the inulin content of treatments that enhance the 
Table (3): Vitamin B complex water soluble vitamins (B complex and Vit c.) of Fresh JA and Bio-yoghurt supplemented with different levels of Jerusalem artichoke extract .

\begin{tabular}{|c|c|c|c|c|}
\hline Vitamin(ug/g). & control & J1 & J2 & J3 \\
\hline B3 & $4.03^{\mathrm{a}}$ & $1.36^{\mathrm{d}}$ & $3.69^{\mathrm{b}}$ & $2.02^{\mathrm{c}}$ \\
\hline B1 & $1.99^{\mathrm{a}}$ & $0.92^{\mathrm{b}}$ & $0.83^{\mathrm{c}}$ & $0.84^{\mathrm{c}}$ \\
\hline B6 & $1.13^{\mathrm{c}}$ & $0.92^{\mathrm{d}}$ & $1.20^{\mathrm{b}}$ & $1.69^{\mathrm{a}}$ \\
\hline B9 & ND & ND & ND & ND \\
\hline B2 & $0.50^{\mathrm{a}}$ & $0.16^{\mathrm{c}}$ & $0.30^{\mathrm{b}}$ & $0.09^{\mathrm{d}}$ \\
\hline B12 & ND & ND & ND & ND \\
\hline The Vit.C & $2.53^{\mathrm{d}}$ & $2.95^{\mathrm{c}}$ & $3.32^{\mathrm{b}}$ & $3.67^{\mathrm{a}}$ \\
\hline
\end{tabular}

a.b ..Means in the same column are bearing different superscripts differ significantly $(\mathrm{P}<0.05)$. ,J1, J2 and $\mathrm{J} 3$ as indicated in Table (1). ND: not detected.

Table (4): Change in $\mathrm{PH}$ values of Bio-yoghurt supplemented with different levels of Jerusalem artichoke extracts.

\begin{tabular}{|l|l|l|l|l|}
\hline \multirow{2}{*}{$\begin{array}{l}\text { Storage period } \\
\text { (day) }\end{array}$} & \multicolumn{4}{|c|}{$\mathbf{p H}$} \\
\hline Zero & \multicolumn{1}{|c|}{ Control } & \multicolumn{1}{|c|}{$\mathbf{J 1}$} & \multicolumn{1}{|c|}{$\mathbf{J 2}$} & $\mathbf{J 3}$ \\
\hline $\mathbf{5}$ & $4.60^{\mathrm{ab}} \pm 0.04$ & $4.50^{\mathrm{ab}} \pm 0.05$ & $4.45^{\mathrm{c}} \pm 0.04$ & $4.40^{\mathrm{c}} \pm 0.02$ \\
\hline $\mathbf{1 0}$ & $4.51^{\mathrm{b}} \pm 0.03$ & $4.20^{\mathrm{d}} \pm 0.0$ & $4.38^{\mathrm{c}} \pm 0.03$ & $4.67^{\mathrm{a}} \pm 0.07$ \\
\hline $\mathbf{1 5}$ & $4.45^{\mathrm{ab}} \pm 0.04$ & $4.16^{\mathrm{d}} \pm 0.04$ & $4.29^{\mathrm{c}} \pm 0.01$ & $4.52^{\mathrm{ab}} \pm 0.04$ \\
\hline
\end{tabular}

a.b ..Means in the same column are bearing different superscripts differ significantly $(\mathrm{P}<0.05)$. $\mathrm{J} 1, \mathrm{~J} 2$ and $\mathrm{J} 3$ as indicated in Table 1 .

culture microorganisms' growth and in turn increasing fermentation of lactose into lactic acid. This result agreed with Zuleta et al. (2004) who mentioned that growth all strains of LAB was promoted by inulin on JA.

Syneresis in bio-yoghurt fortified with 3,5 and 7\% JA water extract is presented by Table(5). Considerable increase was observed in curd syneresis up to the treatment $\mathrm{J}_{3}$ at zero time with significant increase compared to the control. These results could be attributed to the holing capacity of water caused by the oligosaccharides contained in Jerusalem compared to the control by the first day of storage; this increase was progressive at the level of the fresh, the day 5,10and15 the day treatments $\mathrm{J}_{2}$ and $\mathrm{J}_{3}$ recorded the highest value, These samples scored values ranged from (36 to 46 and $41 \mathrm{ml} \backslash 100 \mathrm{ml}$ ) for JA samples at zero time compared to the control sample $(29.53 \mathrm{ml} / 100 \mathrm{ml})$. 
This increase in syneresis has shown also during cold storage between treatments up to 15 days of cold storage in comparing with the control. with the ratio $7 \%$ after 10 days and 5\% JA after 15 days has shown equality compared to the previous samples. Progressive significant increase also observed among all samples and the control and the sample $\mathbf{J}_{1}$ at the level of the days 10 and 15 of storage, which was non-significant between the samples $\mathrm{J}_{2}$ and $\mathrm{J}_{3}(54.99$ to $54.99 \mathrm{ml} \backslash 100 \mathrm{ml})$ but significant with the control, by increasing the storage periods up to the end period. These results had agreed with those obtained by Guven et el., (2005) and Kamaly et al. (2011).

Finally, it can concluded that, as a result of increasing the added ratio of JA extract that led to higher water holding capacity owing to oligosaccharides contained in inulin from Jerusalem artichoke extract that represents, the prebiotic for the used probiotic culture to secret lactic acid, causing an increase in whey syneresis that decreased curd tension, moreover, decreasing viscosity of the produced bio-yoghurt as illustrated in obtained data in Table (5).

Curd tension of JA samples illustrated by the same table, showed significant decrease with increasing the added ratio of JA extract, but the treatment contained 5\% extract revealed the highest curd tension of all treatments at the level of fresh samples and the lowest value after 5 days of cold storage. The average values of this estimate was from (30.58 to $25.55 \%$ ) for treatments $\mathrm{J} 1$ and $\mathrm{J} 3$ compared to the control with significant increase with the sample J2 (32.57\%), for fresh samples and from (31.56 to 29.55\%) with higher decrease for the sample $\mathrm{J} 2(23.55 \%)$ after seven days of cold storage. This incidence decrease in curd tension of the treatments may be attributed to the higher water holding capacity in the resultant treated samples owing to the action of the contained inulin according to Guven et al., (2005) and Kamaly et al. (2011).

On the other hand increasing cold storage period revealed significant increase in curd tension at the level of the control and the treatment $J_{1}$ and $\mathrm{J}_{2}$ sarnples after 5 and 10 days at $5 \pm 1^{\circ} \mathrm{C}$, Which may be attributed to the higher T.S and refrigeration according to El-Shibiny et al.(1977). This increase ranged from 30.57 to $35.55 \%$ for the control and from 27.54 to $35.56 \%$ for the sample $\mathrm{J} 1$ compared to the fresh control $(30.58 \mathrm{gl} 100 \mathrm{gm})$ by increasing storage period up to 10 days. Meanwhile, J2 showed an irregular trend after 5 days of cold storage achieving a lower value. Another decrease was observed among the treatments $5 \%$ and $7 \%$ as compared to the control 
Table (5): Rheological properties of Bio-yoghurt supplemented with different levels of Jerusalem artichoke extract during cold storage.

\begin{tabular}{|c|c|c|c|c|}
\hline \multirow{2}{*}{$\begin{array}{c}\text { Storage } \\
\text { period } \\
\text { (days) }\end{array}$} & \multicolumn{4}{|c|}{ Syneresis $(\mathrm{ml} / \mathbf{1 0 0 m l})$} \\
\hline & Control & $\mathrm{J}_{1}$ & $\mathbf{J}_{2}$ & $\mathbf{J}_{3}$ \\
\hline zero & $29.53^{\mathrm{d}} \pm 0.02$ & $38.00^{\mathrm{c}} \pm 0.02$ & $46.00^{\mathrm{a}} \pm 0.02$ & $41.00^{\mathrm{b}} \pm 007$ \\
\hline 5 & $25.54^{\mathrm{d}} \pm 0.03$ & $49.00^{\mathrm{b}} \pm 005$ & $46.09^{c} \pm 0.06$ & $50.00^{\mathrm{a}}+0.04$ \\
\hline 10 & $25.63^{\mathrm{c}} \pm 0.04$ & $42.08^{\mathrm{b}} \pm 009$ & $54.99^{\mathrm{a}}+0.08$ & $54.99^{\mathrm{a}} \pm 0.03$ \\
\hline 15 & $24.53^{\mathrm{c}} \pm 0.03$ & $42.00^{\mathrm{b}} \pm 007$ & $54.99^{\mathrm{a}} \pm 0.05$ & $54.99^{\mathrm{a}} \pm 0.02$ \\
\hline \multicolumn{5}{|c|}{ Curd tension (g/l00gm) } \\
\hline zero & $30.58^{\mathrm{b}} \pm 0.07$ & $27.55^{\mathrm{c}} \pm 0.02$ & $32.56^{\mathrm{a}} \pm 0.03$ & $25.55^{\mathrm{d}} \pm 0.05$ \\
\hline 5 & $31.56^{\mathrm{a}} \pm 0.03$ & $26.54^{\mathrm{c}} \pm 0.04$ & $23.55^{\mathrm{d}} \pm 0.06$ & $29.56^{\mathrm{b}} \pm 0.07$ \\
\hline 10 & $35.55^{\mathrm{a}} \pm 0.05$ & $35.56^{\mathrm{a}} \pm 0.03$ & $28.54^{\mathrm{b}} \pm 0.08$ & $25.65^{c} \pm 009$ \\
\hline 15 & $25.56^{\mathrm{b}} \pm 0.06$ & $30.56^{\mathrm{a}} \pm 0.04$ & $25.54^{\mathrm{b}} \pm 0.05$ & $24.54^{\mathrm{c}} \pm 0.02$ \\
\hline \multicolumn{5}{|c|}{ Viscosity $(\mathbf{c p})^{*}$} \\
\hline zero & $763.0^{\mathrm{d}} \pm 0.07$ & $1041^{\mathrm{a}} \pm 0.03$ & $871^{b} \pm 0.05$ & $796^{\mathrm{c}} \pm 0.02$ \\
\hline 5 & $571.00^{\mathrm{b}} \pm 0.05$ & $507^{c} \pm 0.06$ & $728^{\mathrm{a}} \pm 008$ & $481^{\mathrm{a}} \pm 0.03$ \\
\hline 10 & $781.00^{\mathrm{b}} \pm 0.09$ & $651^{c} \pm 0.04$ & $841^{\mathrm{a}} \pm 0.02$ & $582^{\mathrm{a}} \pm 0.05$ \\
\hline 15 & $771.00^{b} \pm 0.03$ & $631^{\mathrm{c}} \pm 0.06$ & $831^{\mathrm{a}} \pm 0.08$ & $571^{\mathrm{d}} \pm 0.04$ \\
\hline
\end{tabular}

a.b ..Means in the same column are bearing different superscripts differ significantly $(\mathrm{P}<0.05)$.

$, \mathrm{J}_{1}, \mathrm{~J}_{2}$ and $\mathrm{J}_{3}$ as indicated in Table (1), Cp= Centipoise

sample by increasing storage period. This increase in curd tension owing to the high content of TS and cold storage according to El-Shibiny et al.,(1977).

Generals the decrease in curd tension was owing to higher water holding capacity of the contained oligo and polysaccharides and fibers in JA extract. Also, as a result of proteolysis or lipolysis caused by the organisms and produced lactic acid, which increase acidity.

Bio-yoghurt viscosity fortified with Jerusalem artichoke extract at levels of 3,5 and 7\% JA extract also demonstrated in Table (2). Recorded data showed significant increase in viscosity of fresh Bio- yoghurt with increasing JA extract compared to the control sample and the treatment with $3 \%$ JA extract showed the highest value (10 41 cp) followed by $\mathrm{J}_{2}(871 \mathrm{cp})$. 
A higher decrease in viscosity was observed after 5 days of stored samples, then increased with in significance between differences among all treatments but significant in comparing with the control after 10 and 15 days except for the treatment $\mathrm{J} 2$ that showed considerable increase and their values ranged from 871 to $831 \mathrm{cp}$ ) which had the highest values and superior the con generally. There was no significant difference in the value of viscosity in treatment, during 5, 10 and 15 days of storage. Were illustrated in Table (6), there was a significant increase for the total viable bacterial count TVBC between the control and the treated sample with 3\% JA extract and no Significance in difference with the sample contained $7 \%$ JA extract that recorded the same count $\left(4 \times 10^{6} \mathrm{cfu}\right.$ gm $)$. The TVBC ranged from $4-13 \times 10^{6}$ for control and the sample $3 \%$ and from $4 \times 10^{6}$ for control and the sample $7 \%$; meanwhile, the treatment $\mathrm{J}_{3}$ void of this estimate.

Higher and significant increase in this population was revealed by the $5^{\text {th }}$ day with control, which was gradually by increasing the added ratio of JA extract; this decrease significant and ranged from $25 \times 10^{7} \mathrm{cfu} / \mathrm{gm}$ for the control to for the sample containing $5 \%$ and the sample in $7 \% \mathrm{JAE}$. On the other hand, the TVBC of the control reused up to the storage period 10 days to be $18 \times 10^{7}$ to by increasing the added ratio of JAE to reach to 15 and the samples $J_{1}$ and $J_{2}$ then decreased to reach $18 \times 10^{7}$ for respectively. These results agreed with (Hashmi et al., 2011. EL-Alfy et al., 2012).15days of cold storage, the control sample showed increase in this estimate $\left(22 \times 10^{7} \mathrm{cfu} / \mathrm{gm}\right)$ that gradually $\mathrm{t}$ the level of the samples $\mathbf{J}_{2}$ and $\mathbf{J}_{1}$ followed by $\mathbf{J}_{3}$ giving for $\left(22,18 \times 10^{7}\right.$ and $14 \times 10^{7}$ cuflgm) respectively. This result may be related the higher increase of molds and yeasts by increasing storage period.

In the same Table, the growth and viability of lactic acid bacteria showed higher and progressive increase as seen in the amples contained JA extract at levels of 3,5 and 7\% resulted in iigh1y significance between treated samples and the control than those of supplementing with TNM and gave the total counts $\left(58.75,76.41 \times 10^{8}\right.$ for the 3 and $5 \%$ treatments and then decreased significantly to reach $89.75 \times 10^{6}$ for the treatment $7 \%$ respectively This higher increase in this population may be related to the higher inulin content and other sugars as previously seen in this work.Molds and yeasts enumeration of Bio-yoghurt as affected by supplementing with JAE are registered in the same table. No numbers of these populations recorded in fresh samples as affected by higher heat of milk and the used ingredients and phenolic compounds contained in both Jerusalem artichoke. 
Table (6): Total bacteria count, Total Lactic acid and Mold\&Yeast(cfu/gm) of Bio-yoghurt supplemented with different levels of Jerusalem artichoke extract during storage period at $5^{0} \mathrm{C} \pm 1$ storage temperature.

\begin{tabular}{|c|c|c|c|c|}
\hline \multicolumn{5}{|c|}{ Treatments } \\
\hline Storage period(days) & Control & $\mathbf{J}_{1}$ & $\mathbf{J}_{2}$ & $\mathbf{J}_{3}$ \\
\hline Zero & $4 \times 10^{6}$ & $13 \times 10^{6}$ & ND & $13 \times 10^{6}$ \\
\hline 5 & $25 \times 10^{7}$ & $14 \times 10^{7}$ & $10 \times 10^{7}$ & $10 \times 10^{7}$ \\
\hline 10 & $17 \times 10^{7}$ & $22 \times 10^{7}$ & $13 \times 10^{7}$ & $18 \times 10^{7}$ \\
\hline 15 & $23 \times 10^{7}$ & $18 \times 10^{7}$ & $22 \times 10^{7}$ & $15 \times 10^{6}$ \\
\hline Total lactic acid & $14.53 \times 10^{6}$ & $58.75 \times 10^{8}$ & $76.41 \times 108$ & $89.75 \times 10^{6}$ \\
\hline \multicolumn{5}{|l|}{ Mold } \\
\hline Zero & ND & ND & ND & ND \\
\hline 5 & $1 \times 10^{5}$ & $4 \times 10^{5}$ & ND & $1 \times 10^{5}$ \\
\hline 15 & $2 \times 10^{5}$ & ND & $2 \times 10^{5}$ & $1 \times 10^{5}$ \\
\hline \multicolumn{5}{|l|}{ Yeast } \\
\hline Zero & ND & ND & ND & ND \\
\hline 5 & $1 \times 10^{5}$ & $2 \times 10^{5}$ & $2 \times 10^{5}$ & $2 \times 10^{5}$ \\
\hline 15 & $2.5 \times 10^{5}$ & $1 \times 10^{5}$ & $0.5 \times 10^{5}$ & ND \\
\hline
\end{tabular}

Survival of molds and yeasts appeared and developed within the first week of cold storage with higher increase in total viable counts ranged from the treatment supplemented with This increase recorded $4 \times 10^{5}$ for JA sample contained $3 \%$-ict after 5days and the sample contained $7 \%$ equaled with the control the $\left(1 \times 10^{5}\right)$ and not detected in the treatment with $5 \%$.

Another increase was observed after 10 days of cold storage or the survival of molds and yeasts for the control sample, but showed decrease among treatments by the day $10^{\text {th }}$.At the same time, the molds not detected in the sample containing 3\% JA react and not detected in samples containing 3\% JA These results often related to the action of LAB on cots and other contained oligosaccharides producing acidity that hence growth of molds and yeasts.

Obtained data for Psychrophilic bacteria showed that it did not detect in Bio- yoghurt with supplemented with Jerusalem artichoke extract at different levels of supplementation or storage periods at $5 \pm 1{ }^{\circ} \mathrm{C}$ and all their values were zero because of higher heat treatment of milk used in manufacture of the produced Bio-yoghurt and phenolic compounds contained in both tubers which act as antimicrobials and antioxidant. 
From Table (7), it could be observed that addition Jerusalem artichoke extracts improved the flavor of resultant -yoghurt compared to control at zero time, which scored 9.25 nd 9.65, respectively. Yoghurt samples, treated by $5 \%$ JA had the highest scores color, flavor, appearance, texture and overall acceptability compared to yoghurt control, which recorded $(9.82,9.62,9.62)$. and $9.65,9.44,9.25,9.26,8.25$ and 8.97 respectively.

Table (7): Sensory evaluation of Bio-yoghurt supplemented with different levels of Jerusalem artichoke extract during cold storage.

\begin{tabular}{|c|c|c|c|c|}
\hline \multirow{2}{*}{$\begin{array}{c}\text { Storage } \\
\text { period(days) }\end{array}$} & \multicolumn{4}{|c|}{ Color } \\
\hline & Control & $\mathbf{J}_{1}$ & $\mathbf{J}_{2}$ & $\mathbf{J}_{\mathbf{3}}$ \\
\hline Zero & $9.44^{\mathrm{b}} \pm 002$ & $9.82^{\mathrm{a}} \pm 0.04$ & $9.82^{\mathrm{a}} \pm 0.03$ & $9.82^{\mathrm{a}} \pm 02$ \\
\hline 5 & $9.09^{\mathrm{b}} \pm 0.03$ & $8.70^{c} \pm 0.05$ & $9.15^{\mathrm{a}} \pm 0.06$ & $8.03^{\mathrm{c}} \pm 0.07$ \\
\hline 10 & $7.88^{\mathrm{d}} \pm 0.08$ & $9.06^{\mathrm{a}} \pm 0.03$ & $8.47^{b} \pm 0.09$ & $8.00^{b} \pm 0.07$ \\
\hline 15 & $7.20^{\mathrm{c}} \pm 0.04$ & $8.55^{\mathrm{a}} \pm 0.07$ & $8.09^{b} \pm 0.03$ & $8.03^{\mathrm{b}} \pm 0.02$ \\
\hline \multicolumn{5}{|c|}{ Flavour } \\
\hline Zero & $9.25^{\mathrm{b}} \pm 0.07$ & $9.60^{\mathrm{a}} \pm 0.05$ & $9.62^{\mathrm{a}} \pm 0.04$ & $9.65^{\mathrm{a}} \pm 0.06$ \\
\hline 5 & $8.49^{\mathrm{b}} \pm 0.03$ & $7.38^{\mathrm{d}} \pm 0.06$ & $8.70^{\mathrm{a}} \pm 0.04$ & $8.12^{\mathrm{c}} \pm 0.07$ \\
\hline 10 & $7.50^{\mathrm{d}} \pm 0.05$ & $8.37^{\mathrm{a}} \pm 0.03$ & $8.23^{\mathrm{b}} \pm 0.04$ & $8.04^{\mathrm{c}} \pm 0.02$ \\
\hline 15 & $7.03^{\mathrm{b}} \pm 0.06$ & $8.10^{\mathrm{a}} \pm 0.07$ & $8.06^{\mathrm{a}} \pm 0.05$ & $8.00^{\mathrm{a}} \pm 0.03$ \\
\hline \multicolumn{5}{|c|}{ Appearance } \\
\hline Zero & $9.26^{\mathrm{b}} \pm 0.09$ & $9.61^{\mathrm{a}} \pm 0.07$ & $9.62^{\mathrm{a}} \pm 0.03$ & $9.63^{\mathrm{a}} \pm 0.07$ \\
\hline 5 & $8.55^{\mathrm{b}} \pm 0.05$ & $8.24^{\mathrm{c}} \pm 0.04$ & $8.85^{\mathrm{a}} \pm 0.06$ & $8.35^{\mathrm{b}} \pm 0.03$ \\
\hline 10 & $7.03^{\mathrm{d}} \pm 0.07$ & $8.86^{\mathrm{a}} \pm 0.03$ & $8.38^{\mathrm{b}} \pm 0.09$ & $8.09^{c} \pm 0.02$ \\
\hline 15 & $7.01^{\mathrm{c}} \pm 0.08$ & $8.52^{\mathrm{a}} \pm 0.02$ & $8.03^{\mathrm{b}} \pm 00^{\prime} 7$ & $8.00^{\mathrm{b}} \pm 0.05$ \\
\hline \multicolumn{5}{|c|}{ Texture } \\
\hline Zero & $8.25^{\mathrm{c}} \pm 0.08$ & $9.62^{\mathrm{a}} \pm 004$ & $9.44^{\mathrm{b}} \pm 0.06$ & $9.40^{\mathrm{b}} \pm 0.07$ \\
\hline 5 & $8.27^{\mathrm{a}} \pm 0.06$ & $7.85^{\mathrm{c}} \pm 0.03$ & $8.25^{\mathrm{a}} \pm 0.05$ & $8.00^{b} \pm 0.02$ \\
\hline 10 & $6.87^{\mathrm{d}} \pm 0.07$ & $8.63^{\mathrm{a}} \pm 0.02$ & $8.37^{\mathrm{b}} \pm 0.04$ & $7.87^{\mathrm{c}} \pm 0.08$ \\
\hline 15 & $6.60^{\mathrm{c}} \pm 0.08$ & $8.10^{\mathrm{a}} \pm 0.02$ & $8.03^{a} \pm 0.04$ & $7.40^{\mathrm{b}} \pm 0.09$ \\
\hline \multicolumn{5}{|c|}{ Overall Acceptability } \\
\hline Zero & $8.97^{\mathrm{c}} \pm 0.05$ & $9.65^{\mathrm{a}} \pm 0.03$ & $9.58^{\mathrm{b}} \pm 0.07$ & $9.57^{b} \pm 0.06$ \\
\hline 5 & $8.41^{\mathrm{b}} \pm 0.09$ & $8.44^{\mathrm{b}} \pm 0.08$ & $8.72^{\mathrm{a}} \pm 0.05$ & $8.13^{\mathrm{c}} \pm 0.03$ \\
\hline 10 & $7.33 \mathrm{~d} \pm 0.02$ & $8.66^{\mathrm{a}} \pm 0.05$ & $8.28^{\mathrm{b}} \pm 0.03$ & $8.11^{\mathrm{c}} \pm 0.04$ \\
\hline 15 & $7.07^{\mathrm{d}} \pm 0.03$ & $8.65^{\mathrm{a}} \pm 0.09$ & $0.02 \pm 8.09^{b}$ & $8.06^{\mathrm{c}} \pm 0.04$ \\
\hline
\end{tabular}

a.b ..Means in the same column are bearing different superscripts differ significantly $(\mathrm{P}<0.05)$. $, \mathrm{J} 1, \mathrm{~J} 2$ and $\mathrm{J} 3$ as indicated in Table (1). ND: not detected 
On the other hand, storage period effect in all sensory racteristics by decreasing, which was higher in control Bio-yoghurt than other treated samples by different level of JAE cially after 15 day of storage at $5^{\circ} \mathrm{C}$.

Statistical analysis revealed significant increase in scored values obtained by panelists for Bio-yoghurt color of fresh treated Tuples with JA extract at level of J1 (9.82), J2 (9.82) and J3 (9.82)degree supersizing the control sample (9.44). Regularly flavor and overall acceptability at zero time of manufacture saved the same behavior scoring the highest numbers comparing with the count

Conclusively, from these results, it could be concluded that supplementation dairy products with Jerusalem artichoke as treatment for diabetes. Because if it was approved that it reduces the level of glucose in blood, because they contain many vitamins and nutrients necessary and beneficial to human health.

\section{REFERENCES}

A.O.A.C. (2000). Official Method of Analysis. Association of Official Analytical Chemist, $17^{\text {th }}$ Edition, Washington D.C. ,USA

A.O.A.C. (2005).Official Methods of Analysis. Association of Official Analytical.Association of Official Analytica chemists International.18 Ed.Washington,D.C.32.Cerial Food.1-14.

A.O.A.C. (2010). Official Methods of Analysis. Association of Official Analytical.

Abd El-Salam, M. H. ; El-Shibiny, S. ; Mahfouz, M. B. ; El-Dein, H. F. ; ElAtriby,. H. M. and Antila, V. (1991). Preparation of whey protein concentrate from salted whey and its use in yoghurt. J. Dairy Res, 58: 503.

American Public Health Association. (1992). Standard Methods For The Examination Of Dairy Products. Amer. Publ. Health Assoc. Inc. $12^{\text {th }}$ ed., New York, USA.

Aryana, K.J and McGrew, P. (2007). Quality Attributes of Yogurt with Lactobacillus casei and Various Prebiotics. LWT-Food Sci\& Tech., 40(10): 1808-1814 .

Axelsson, G and Bjomsson, G,(1992). Botn in Eyjafjordur County. Report OS-92012/JHD01, National Energy Authority, Reykjavik,71 P. (In Icelandic). 
Barrantes, E.; Tamime, A.Y. and Sword, A.M. (1994). Production of lowcalorie yoghurt using skim milk powder and fat substitute: Microbiological and organoleptic qualities. Milchwissenschaft, 49: 205-208.

Block, R. J.; Durum, E. L and Zweig, G. L. (1958). "A Manual Of Paper Chromatography And Paper Electrophoresis". $2^{\text {nd }}$ edition Academic Press, N.YSPSS (1997)

Buriti,F.C.A.:Cardarelli, H.R.: Filisetti, T.M.C.C and Saad, S.M.I.(2007). Synbiotic Potential of Fresh Cream Cheese Supplemented with Inulin and Lactobacillus Paracssei in Co-Culture with Streptococcus thermophillus. Food Chemistry, 104:1605-1610.

Champagne, C.P.; Tompkins, T.A.; Buckley, N.D and Green Johnson, J.M. (2010). Effect of fermentation by pure and mixed cultures of Streptococcus thermophilus and Lactobacillus herveticus on isoflavone and B. vitamin content of a fermented soy beverage. Food Microbiology, 22:968 Chemist, $17^{\text {th }}$ Edition, Washington D.C

Difco Laboratories Incoroorated. (1984). Difco Manual Culture Media And Reagent Of Dehydrated For Microbiological And Chemical Laboratories. Inc., Detroit michigin, USA.

Duncan,D. B.(1955). Muitiple range and multiple F tests. Biometrics, 1:1-42. Ed., Published by the author, Cornell Univ., Ithaca, New York, USA.

El-Alfy, M.B.; Shenana, M.E., EL-Nagar, G.F and Atallah , A.A. (2012). Growth and survival of some probiotic bacteria under manufacturing condition of yoghurt and Ras cheese. Egypt J. Dairy Sci., 40(2): 123-133.

EL-kholy,Wedad $M$ and Mahrous,Hoda.(2015).Biological Studies Bioyoghurt with Prebiotic Obtained from Jerusalem artichoke. Food \& Nutri. Sci., 6(16):1552-1564.

El-Sayed- Samab, M.; Hagrass, A.F.; Asker, A.A.; Maihat, F.M.; El-Sayed, M.M and Abd El-Salam, M H (2013) Effect of usmg some vitamin B Producing Micioorganisms As Adjunct culture in the manufactuie of Yoghurt. Egypt J. Dairy Sci ,41(2): 127-136.

El-Shenawy, M.; Abd El-Aziz, M., El-kholy, WI.; Fouad , M.T. (2012). Probiotic yoghurt manufactured with tiger-nut extract(cyperusesculentus) as a functional dairy food. J. Agric Res \&Natural Resources, 1(2): 20-31.

EL-Shibiny, S.; Ghita, I and Abdou, S. M. (1977). The use of skim milk powder in the manufacture of yoghurt. Egypt J. Dairy Sci., 5: 109-115. 
Guven, M., K. Yasar, et al. (2005). "The effect of inulin as a fat replacer on the quality of set-type low-fat yogurt manufacture." International Journal of Dairy Technology, 58(3): 180-184.

Guven, M.; Yasar, K.; Karaca, O. B and Hayaloglu, A. A. (2005).The effect of inulin as a fat replacer on the quality of set-type low-fat yogurt manufacture. Int. J. Dairy Tech., 58(3): 180-184

Hashmi, S.I.; Kadam, S.S and Kale, R.V. (2011). Studies on effect of different varieties of date palm paste incorporation on quality characteristics of yoghurt. Elec. J. Environ, Agric. \& Food Chem., 10(6): 2371-2381.

Jackson, N. L (1985). Soil Chemical Analysis. Constable. Ltd.co., London pp:498.

Kailasapathy, Kand Chin, J.(2000).Survival and Therapeutic Potential of Probiotic Organism with Reference to Lactobacillus acidophilus and Bifidobacterium spp. Immunol. \&Cell Biol., 78:80-88.

Kailaspathy, K. (2006).Survival of free and encapsulated probiotic bacteria and encapsulated probiotic bacteria and their effect on the sensory properties of yogurt. LWT-Food Sci\& Tech., 39 (10): 1221-1227.

Kays, S.J and Nottingham, S.F. (2007). Biology and Chemistry of Jerusalem Artichoke: Helianthus tuberosus L .CRC press, Boca Raton .

Letexier, D.; Diraison, F and Beylot, M. (2003). Addition of Inulin to a Moderately High-Carbohydrate Diet Reduces Hepatic Lipogenesis and Plasma Triacylglycerol Concentrations in Humans. American Journal of Clinical Nutrition, 77: 559564.

Nair, K.K.:Kharb,Sand Thompkinson, D.K(2010). Inulin Dietary Fiber with Functional and Health Attributes. A Review. Food Reviews International,26:189-203.

Nielson ,V. H. (1975). Factors which control the body and texture of ,mmercial yoghurts. Amer. Dairy Rev. , 37: 36

Niness, KR (1999). Inulin and oligofrLjctose: what are they?. Journal of Nutrition, 129: S1402

O'Mahoney. F. (1988). Rural Dairy Technolog-Experiences in Ethiopia. ILCA manual No 4. Dairy Technology Unit. ILCA, Addis Abeba, Ethiopia.64 pporganoleptic qualities. Milchwissenschaft, 49: 205-208

SPSS. (1997). SPSS Users Gide Statistics Version 8 copy right. SPSS Inc., USA, Washington, D.C. USA . 
Staffolo, M. D.; Bertola, N.; Martino, $M$ and Bevilacqua, A .(2004).Influence of dietary fiber addition on sensory and rheological properties of yogurt. Int. Dairy J., 14: 263-268.

Tanjor, S.; Judprasong, K.; C and Jogloy, S.(2012). Inulin and Fructooligosaccharides in Different Varies of Jerusalem Artichoke (Helianthus tuberosus L). Asia-Pacific J. Sci \&Tech., KKU Res.J.,17(1):25-34.

Vinas, P.: Lopez-Erroz, C.: Balsalobre, N and Hernandez-Cordoba, M.(2000).Reversed- phase liquid heomatography on an amide stationary phase for the determination of the B group vitamins in baby foods. J. Chromatography A, 1007(2003): 77-84.

Zuleta, A.;Sarchi,M.I.; Rio,M.E.; Sambucetti, M.E.;Mora,M.;Fabrizio, S.V and Parada, J.L.(2004). Fermented milk-starch and milk-inulin Products as vehicles for lactic acid bacteria. Plant-Foods for-Human Nutri., 59(4):155-160. 


\section{تلعيم الزبادي الحيوي باستخدام الطرطوفة كمصدر طبيعي}

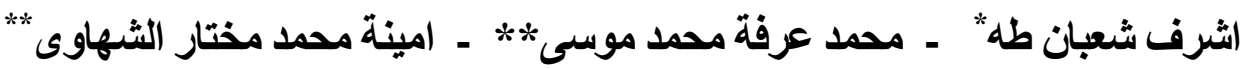

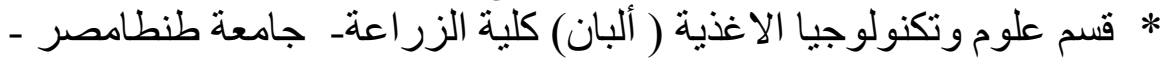

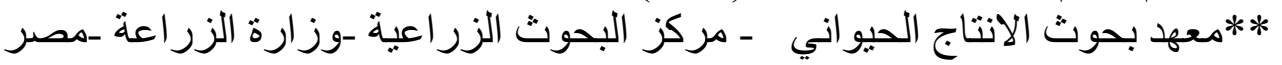
تم استخدام درنات الطرطوفه في تدعيم الزبادي الحيوي المنتج باستخدام

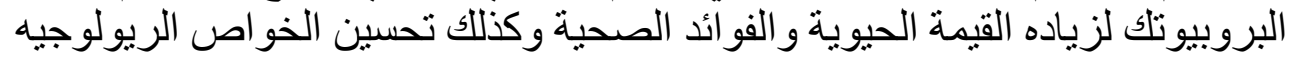
و الفيزوكيميائيه و الحسيه للمنتج الفيهة النهائي.

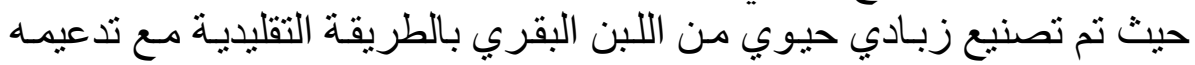

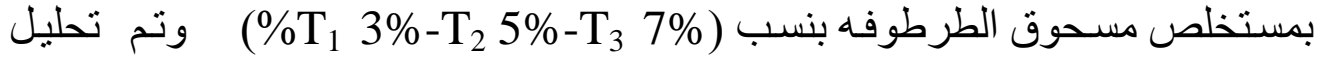

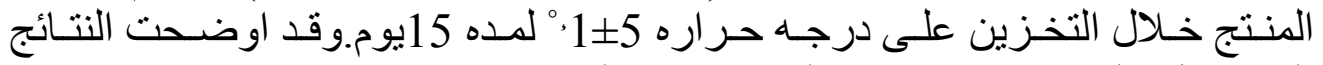

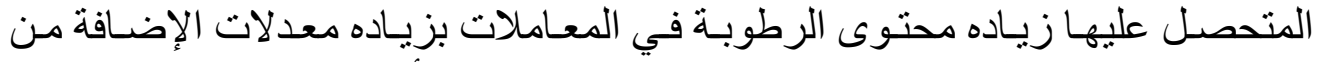

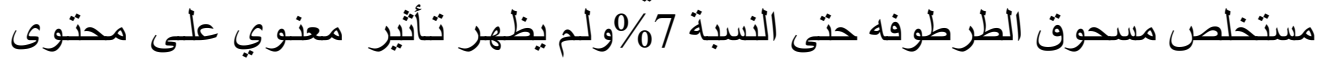

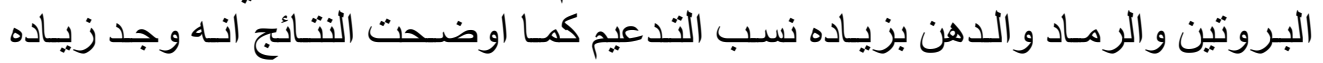

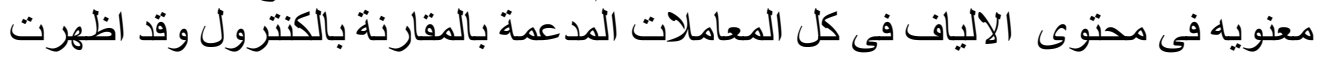

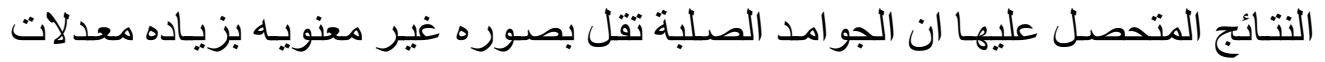

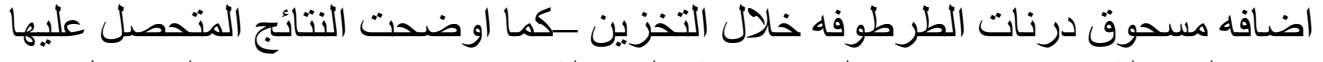

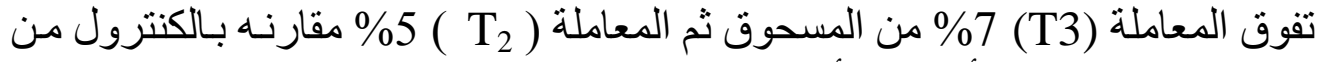

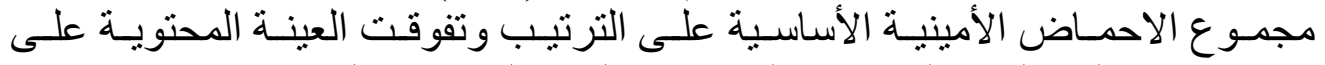

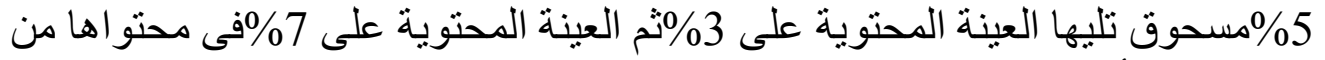

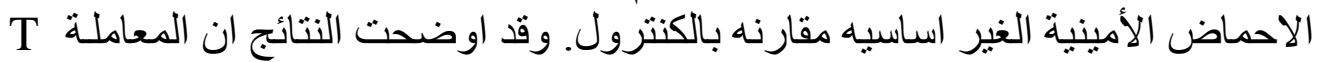

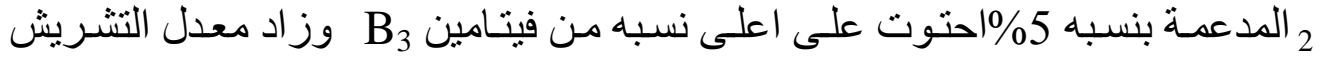

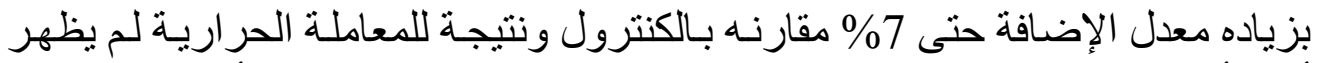

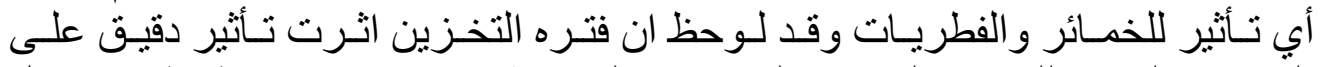

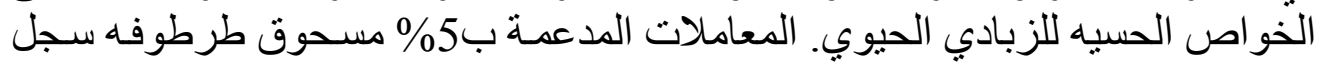

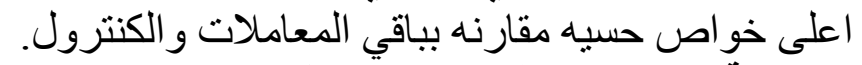

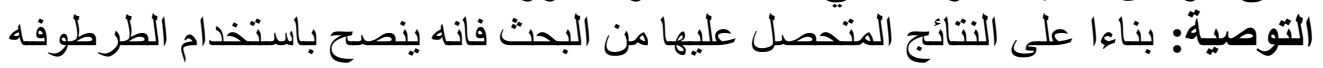

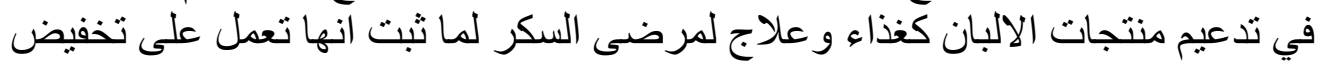

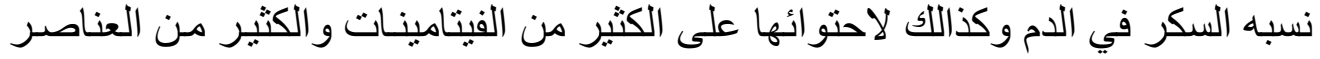

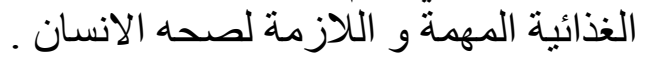

